\title{
Evaporative resistance of newly designed bicycle helmets
}

\author{
Kalev Kuklane ${ }^{1 *}$, Helena Aljaste ${ }^{2}$, Sixten S Heidmets ${ }^{2}$, COST Action TU1101 WG4 ${ }^{3}$ \\ From 15th International Conference on Environmental Ergonomics (ICEE XV) \\ Portsmouth, UK. 28 June - 3 July 2015
}

\section{Introduction}

As a continuation of the work on the ventilation requirements for a bicycle helmet for commuters [1], 15 full scale helmet mock-ups were created and tested for dry heat loss properties [2] in a wind tunnel on a thermal head manikin [3]. This paper presents the results of the wet heat transfer measurements in the form of evaporative resistance.

\section{Methods}

The helmets were tested in the wind tunnel placed in a climatic chamber at $34{ }^{\circ} \mathrm{C}$ and $40 \%$ relative humidity (water vapour pressure in the air $2200 \mathrm{~Pa}$ ) with the air velocities set to $1.6 \mathrm{~m} / \mathrm{s}(\approx 6 \mathrm{~km} / \mathrm{h})$. Tests were performed on the head model without a wig. Evaporative resistance was calculated from heat loss corrected for the difference in head surface to textile skin temperature [4]. One (TK) of the 15 mock-ups was tested back to front, too (TKo). In addition, 4 commercially available helmets were tested as reference. Three of them were one of the best, one average and one of the less well performing helmets of the study by Brühwiler et al. [5], and one was a helmet often bought and used by commuters.

\section{Results}

The prototypes differed largely in evaporative resistance (Figure 1).

\section{Discussion}

The best reference helmet from the earlier study [5] stayed approximately in the middle of the tested range while the poorest reference helmet was in the end of

\footnotetext{
* Correspondence: kalev.kuklane@design.lth.se

'The Thermal Environment Laboratory, Division of Ergonomics and Aerosol Technology, Department of Design Sciences, Faculty of Engineering, Lund University, Lund, Sweden

Full list of author information is available at the end of the article
}

the line with an often used one as the worst (Figure 1). Thus, the newer solutions performed much better from an evaporation viewpoint than commercially available helmets. However, the order of the helmets in the "best function line" for evaporation was different from their insulation performance, as reported previously [2].

\section{Conclusion}

The best helmet from the evaporation viewpoint was different from the best in terms of insulation. This means that a best solution for a commuter has to be defined by the user's bicycling activity, the weather conditions etc. The newly designed helmets' results can be used as the basis for improvement of helmet ventilation.

\section{Authors' details}

${ }^{1}$ The Thermal Environment Laboratory, Division of Ergonomics and Aerosol Technology, Department of Design Sciences, Faculty of Engineering, Lund University, Lund, Sweden. ${ }^{2}$ Department of Product Design, Estonian Academy of Arts, Tallinn, Estonia. ${ }^{3} \mathrm{HOPE}$-Helmet OPtimization in Europe, COST Action TU1101 Working Group 4 with the participation of Jean-Marie Aerts, Helena Aljaste, Simon Annaheim, Cornelis P Bogerd, Peter Bröde, Guido De Bruyne, Andreas D Flouris, Sixten S Heidmets, Anica Hursa, Kalev Kuklane, Tiago S Mayor, René M Rossi.

Published: 14 September 2015

\section{References}

1. Kuklane K, Heidmets SS, COST Action TU1101 WG4: User friendly bicycle helmet for commuters. Proceedings of the International Cycling Safety Conference 2013, 20-21 November 2013 Helmond, The Netherlands;4.

2. Aljaste H, Kuklane K, Heidmets SS: COST Action TU1101 WG4. Better Bicycle Helmets for Commuters - Evaluation of Ventilation. Proceedings of the International Cycling Safety Conference 18-19 November 2014, Gothenburg, Sweden; 2014, 7.

3. Liu X, Holmér I: Evaluation of evaporative heat transfer characteristics of helmets. Applied Human Science. Journal of Physiological Anthropology 1997, 16(3):107-113.

4. Wang F, Kuklane K, Gao C, Holmér I: Development and validity of a universal empirical equation to predict skin surface temperature on thermal manikins. Journal of Thermal Biology 2010, 35(4):197-203.
C Biomed Central

(c) 2015 Kuklane et al. This is an Open Access article distributed under the terms of the Creative Commons Attribution License (http:// creativecommons.org/licenses/by/4.0), which permits unrestricted use, distribution, and reproduction in any medium, provided the original work is properly cited. The Creative Commons Public Domain Dedication waiver (http://creativecommons.org/publicdomain/ zero/1.0/) applies to the data made available in this article, unless otherwise stated. 


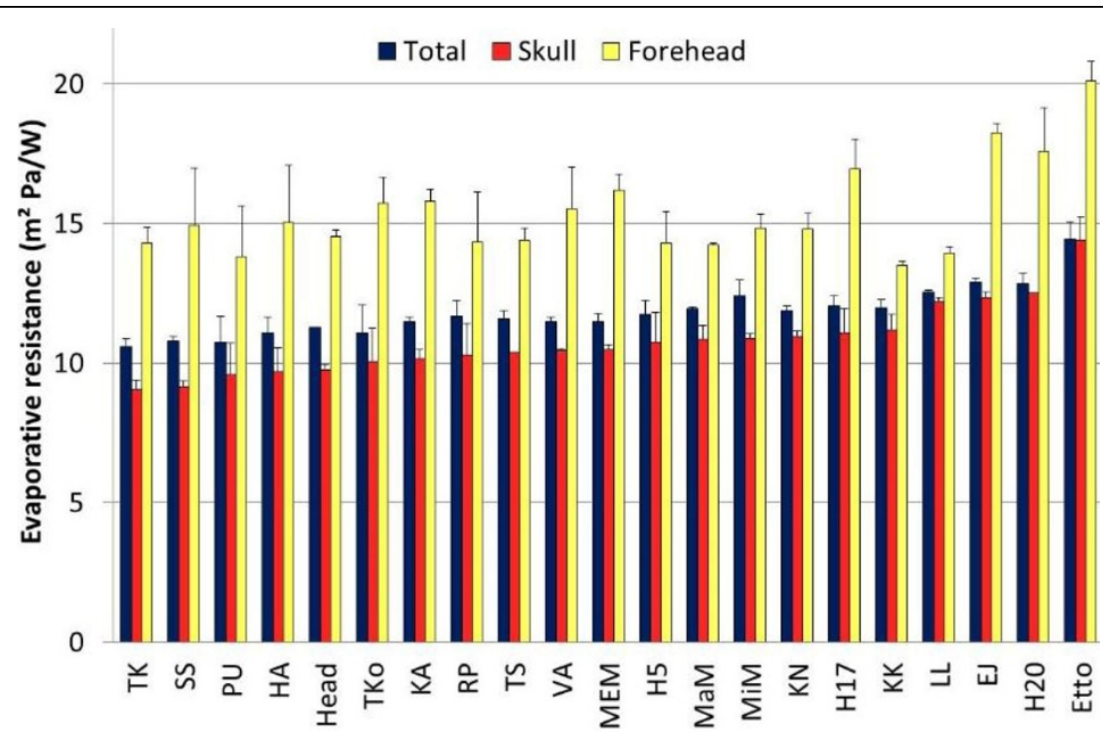

Figure 1 Evaporative resistance of design helmets at $1.6 \mathrm{~m} \cdot \mathrm{s}^{-1}$ wind and $34{ }^{\circ} \mathrm{C}$ with a wet textile skin

5. Brühwiler PA, Buyan M, Huber R, Bogerd CP, Sznitman J, Graf SF, Rösgen T: Heat transfer variations of bicycle helmets. Journal of Sports Sciences 2006, 24(9):999-1011.

doi:10.1186/2046-7648-4-S1-A72

Cite this article as: Kuklane et al:: Evaporative resistance of newly

designed bicycle helmets. Extreme Physiology \& Medicine 2015 4(Suppl 1): A72.
Submit your next manuscript to BioMed Central and take full advantage of:

- Convenient online submission

- Thorough peer review

- No space constraints or color figure charges

- Immediate publication on acceptance

- Inclusion in PubMed, CAS, Scopus and Google Scholar

- Research which is freely available for redistribution 